\title{
Growth and Vigor Analysis of Crimson Clover Seeds Obtained Through Different Seeds Size
}

\author{
Ítala T. P. Dubal ${ }^{1}$, Ivan R. Carvalho ${ }^{1}$, Vinícius J. Szareski ${ }^{1}$, João R. Pimentel ${ }^{1}$, Cristian Troyjack $^{1}$, \\ Gustavo H. Demari ${ }^{1}$, Giordano G. Conte ${ }^{1}$, Velci Q. de Souza ${ }^{2}$, Carlos E. S. Pedroso ${ }^{1}$, Francisco A. Villela ${ }^{1}$, \\ Tiago Pedó ${ }^{1} \&$ Tiago Z. Aumonde ${ }^{1}$ \\ ${ }^{1}$ Department of Plant Science, Federal University of Pelotas, Capão do Leão, RS, Brazil \\ ${ }^{2}$ Federal University of Pampa, São Gabriel, RS, Brazil \\ Correspondence: Ivan R. Carvalho, Department of Plant Science, Federal University of Pelotas, Eliseu Maciel, \\ Capão do Leão, RS, Brazil. E-mail: jrobertopimentel@hotmail.com
}

Received: July 8, 2018

doi:10.5539/jas.v11n2p548
Accepted: December 9, $2018 \quad$ Online Published: January 15, 2019

URL: https://doi.org/10.5539/jas.v11n2p548

\begin{abstract}
The objective to evaluate the effect of the size of the crimson clover seeds under the vigor of produced seeds, as well the growth and development throughout the crop cycle. The work was conducted in the experimental area of the Plant Science Department of the Federal University of Pelotas, in the state of Rio Grande do Sul, Brazil. It were used crimson clover seeds (Trifolium incarnatum L.), cultivar "Crimson Clover". The seeds size effect affected the growth and the partition of the assimilated in the crimson clover plants, where medium size seeds raise the biomass accumulation in the different plants structures. Seeds of crimson clover produced from plants originated from different seed sizes did not presented difference in relation to the physiologic quality, seedling emergence and speed of emergence index.
\end{abstract}

Keyworeds: Trifolium incarnatum L., seed production, phenotypic measures of interest

\section{Introduction}

The crimson clover (Trifolium incarnatum L.) is an annual dicotyledonous legume, cultivated in environments with temperate clime (Brant et al., 2009; Kramberger, 2013). It is characterized as a plant with good vigor and erect growth habit, which can be grown in monoculture or polyculture and being productive in different climate conditions (Ball \& Lacefield, 2000; Hackney et al., 2007; USDA, 2013). In order to achieve high productivity in the field, it is necessary to choose seeds with determined characteristics, as high physic and physiologic quality, since the seeds are the main crop input that are produced following the demanding standards of the Brazilian Seeds and Seedlings System (Miyamoto, 2013). The seeds stand out by its genetic, physic, physiologic and sanitary attributes, that allow to originate high productivity plants with superior final quality (Peske et al., 2012; Szareski et al., 2018a).

The seeds physic attributes are important to the implementation of crops at the field, where the seeds size is a parameter that can determine the effects on the physiologic quality (Pádua, 2010; Torres, 1994), although, it is underused to clover seeds. Nevertheless, in crops seeds it is observed positive effects of the size of the seeds in the physiologic quality and production (Bredemeier, 2001; Pádua, 2010; Cangussú, 2013). The size of the seeds is a considerable factor to the germination and initial phase of the crops growth, but the seeds size difference is conditioned to the dissimilarities in the reserve amounts, affecting the crop growth and development on aposteriori (Ahirwar, 2012; Szareski et al., 2018b).

The determination of the seeds physiologic quality can be realized based on the vigor and germination tests (Silva \& Cicero, 2014). The seeds vigor encloses severalcharacteristics that express the emerging potential and quick establishment of regular crops in relation to the conditions in which they are exposed (ISTA, 2006). The seeds considered vigorous are the ones that will have a better establishment at the field conditions, these seeds, once more, present high initial growth and good development when submitted to unfavorable environments (Tillmann \& Menezes, 2012).

The growth analysis is an applied tactic to evaluate the vegetal growth through the ontogeny of crops. Based on the curves, it is possible to interpret physiologic processes and analyze the plant primary production in the 
various growth environments. The knowledge about growth allows evaluating the contribution of the distinguished vegetal structures in the accumulation of dry matter and the cultures yield, thus allowing the development of morphophysiologic processes about the vegetal yield (Peixoto, 2009). The growth analysis is an easy and precise method, which can be and used to evaluate the crop reaction to the diversity of environment and management (Aumonde et al., 2013), allows inferring about the intrinsic dynamics to the different physiologic processes. In this way, this wok had the objective to evaluate the effect of the size of thecrimson clover seeds under the vigor of produced seeds, as well the growth and development throughout the crop cycle.

\section{Material and Methods}

The work was conducted in the experimental area of the Plant Science Department of the Federal University of Pelotas, in the state of Rio Grande do Sul, Brazil (latitude 31 ${ }^{\circ} 52^{\prime} \mathrm{W}$ and altitude $13 \mathrm{~m}$ ). The region climate is temperate with well distributed rains and warm summer, classified as Cfa type according to Köppen (Maluf, 2000).

It were used crimson clover seeds (Trifolium incarnatum L.), cultivar "Crimson Clover", where the sowing was realized in the first fortnight of July 2016. The experimental units were constituted by ten lines of three meters of length, spaced with 0.17 meters, accounting for $5.10 \mathrm{~m}^{2}$ each experimental unit. The fertilizing followed the crop exigency based on the Fertilizing and Liming Manual (CQFS, 2004).

The temperature, solar radiation, relative air humidity and rainfall were collected during the experiment period. Its weekly average can be observed at Figure 1.

The treatments were constituted of three seeds size, classified through the use of sieves specific to small seeds. In this manner, the larger seeds composed the retained material at the sieve of $2.2 \mathrm{~mm}$, medium seeds were retained at the sieve $1.8 \mathrm{~mm}$ and small seeds were retained at the sieve $1.41 \mathrm{~mm}$. In order to better represent the seeds dimensions, 20 seeds were measured per repetition, were using a digital pachymeter the following dimensions were measured: large size (length $3.09 \mathrm{~mm}$, width $2.41 \mathrm{~mm}$ and thickness $1.99 \mathrm{~mm}$ ), medium size (length $2.65 \mathrm{~mm}$, width $2.06 \mathrm{~mm}$ and thickness $1.75 \mathrm{~mm}$ ) and small size (length $2.3 \mathrm{~mm}$, width $1.63 \mathrm{~mm}$ and thickness 1.35). It was utilized these dimensions due to, during the stratification, these sieves obtained the larger amounts of retained materials. For the evaluation of the size effect on the physiologic potential of the seeds, the following tests were performed:

(1) Growth Analysis: the growth evaluations were obtained thru successive collections with 14 days of interval from the seedling emergence, collecting five plants per plot in every evaluation, going through the whole crop cycle, totalizing 11 collections, where the following characters were measured:

Foliar Area $(A f)$ : determined using the area measurer Licor model LI-3100® and foliar area index (L) calculated by the formula $\mathrm{L}=\mathrm{Af} / \mathrm{St}$, where $\mathrm{St}$ correspond to soil superficies.

Root Dry Matter and Shoot: the seedlings were separated between root and shoot, and conditioned in kraft paper envelopes. To obtain the dry matter, the material was transferred to a greenhouse with forced ventilation at the temperature of $70 \pm 2{ }^{\circ} \mathrm{C}$, during 72 hours and weighted with a precision balance.

Total Dry Matter $(W t)$ : adjusted by the simple logistic equation, $\mathrm{Wt}=\mathrm{Wm} /\left(1+\mathrm{A} \cdot \mathrm{e}^{-\mathrm{Bt}}\right)$, where "Wm" is the asymptotic estimation of maximum growth, "A" and "B" constant of adjustment, "e" the natural base of neperian logarithm and " $\mathrm{t}$ " the time, in day, after emergence (Richards, 1969).

The foliar area (Af) data and leaves dry matter (Wf) were adjusted thru orthogonal polynomials (Richards, 1969). The instantaneous values of production rate of dry matter $(\mathrm{Ct})$ were obtained thru derivatives from adjusted equations of the total dry matter (Wt) in relation to the time (Radford, 1967).

Relative Growth Rate $(R w)$ : to determine the instantaneous values of Rw the following equation were used: $\mathrm{Rw}$ $=1 / \mathrm{Wt} \cdot \mathrm{dW} / \mathrm{dt}$.

Net Assimilation Rate $\left(E_{a}\right)$, Foliar Area Ratio $\left(F_{a}\right)$ and Specific Foliar Area $\left(S_{a}\right)$ : the instantaneous values of $\left(\mathrm{E}_{\mathrm{a}}\right)$, $\left(\mathrm{F}_{\mathrm{a}}\right)$ and $\left(\mathrm{S}_{\mathrm{a}}\right)$ were estimated thru the equations: $\mathrm{E}_{\mathrm{a}}=1 / \mathrm{A}_{\mathrm{f}} \cdot \mathrm{d}_{\mathrm{W}} / \mathrm{dt} ; \mathrm{F}_{\mathrm{a}}=\mathrm{A}_{\mathrm{f}} / \mathrm{W}_{\mathrm{t}}$ and $\mathrm{S}_{\mathrm{a}}=\mathrm{A}_{\mathrm{f}} / \mathrm{W}_{\mathrm{f}}$, according to Radford (1967).

(2) Dry Matter Partition: it were used, among the plants growth and development, the fractions between roots, stems, leaves and inflorescence. Separately, from the gauging of the mass allocated in each vegetal structure, followed by the transformation of the primary data, prevenient from the dry matter of each organ, to percentage.

(3) Vigor of Produced Seeds: at the 154 days after emergence the seeds harvest was realized, with $18 \%$ humidity. Afterwards they were submitted to kiln-drying under temperature of $35^{\circ} \mathrm{C}$ until humidity homogenization to $12 \%$, where the following tests were applied: 
Field Emergence (E\%): realized with eight repetitions of 50 seeds sowed in lines spaced by $20 \mathrm{~cm}$, where the design used was randomized blocks. The evaluations were realized at the 14 days after sowing and the results are expressed in percentage of normal seedlings.

Velocity of Emergence Index (IVE): obtained from the daily counting of emerged seeds. The counting were realized until a constant number of emerged seedlings (Vieira \& Carvalho, 1994).

The experimental design utilized was the randomized blocks, organized in factorial scheme, being three seeds sizes: large size (length $3.09 \mathrm{~mm}$, width $2.41 \mathrm{~mm}$ and thickness $1.99 \mathrm{~mm}$ ), medium size (length $2.65 \mathrm{~mm}$, width $2.06 \mathrm{~mm}$ and thickness $1,75 \mathrm{~mm}$ ) and small size (length $2.3 \mathrm{~mm}$, width $1,63 \mathrm{~mm}$ and thickness 1.35 ) $\times 11$ harvesting dates $(14,28,42,56,70,84,98,112,126,140$ and 154 after emergence), prepared in three repetitions.

The total dry matter data were analyzed by the logistical simple equation and the discussion was based on the growth curves tendency (Lopes \& Lima, 2015). The assimilated partition data were converted in dry matter percentage allocated in the vegetal structure. Those referred to the primary growth data were submitted to variance analysis of 5\% probability, where the interaction between seeds size $\times$ harvesting date were tested and, when significant, dismembered its simple effects.
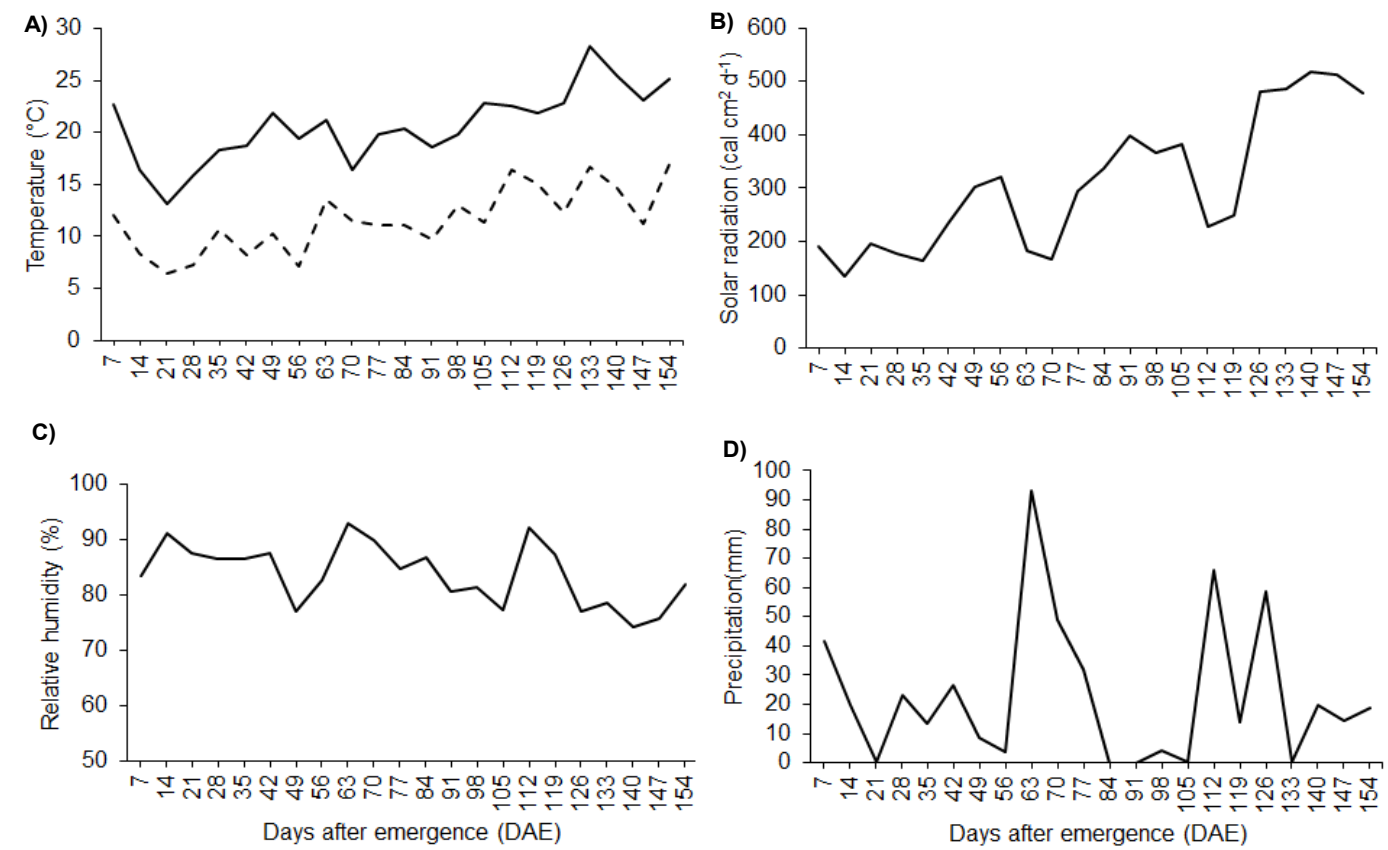

Figure 1. Maximum temperature (-) and minimum (- - ) (A), solar radiation (B), air relative humidity (C) and rainfall (D). Source: Agrometeorological Station of Pelotas

\section{Results and Discussion}

During the period of the experiment conduction the maximum and minimum air temperature average, maximum solar radiation, relative humidity and accumulated precipitation were $21{ }^{\circ} \mathrm{C}$ and $11.5{ }^{\circ} \mathrm{C}, 518 \mathrm{cal} \mathrm{cm} \mathrm{d,} 83 \%$ and $507.6 \mathrm{~mm}$ respectively (Figure 1). In relation to the adaptation of the trifolium genre, the observed climatic conditions were adjusted to the species growth and development, mostly in relation to the optimal temperature to the plants growth and development (Hart, 1987).

The variance analysis revealed probability of $5 \%$ significance to the seeds size $\mathrm{x}$ harvesting date interaction (Table 1) to the characters: foliar area (Af), shoot dry matter aérea $\left(\mathrm{W}_{\mathrm{pa}}\right)$, root dry matter $\left(\mathrm{W}_{\mathrm{r}}\right)$ and leaf dry matter $\left(\mathrm{W}_{\mathrm{f}}\right)$. No significant difference was evinced for the seedlings emergence $(\mathrm{E})$ and velocity of seedlings emergence index (IVE). The total dry matter $\left(\mathrm{W}_{\mathrm{t}}\right)$ production in the crimson clover plants, in the varied seeds size, presented logical tendency, with elevated determination coefficient $\left(\mathrm{R}^{2} \geq 0,82\right)$. The growth initially presented slowly until the 70 days after emergence (DAE), and evidenced its maximum at 154 DAE (Figure 1a). The plants originated from medium size seeds revealed more dry matter accumulation when compared to those plants obtained thru 
large and small sized seeds. The accumulation of dry matter is related to the foliar area arrangement and to the elevated net assimilation rate (Aumonde et al., 2011).

Table 1. Resume of the variance analysis with the mean square of the foliar area $\left(\mathrm{A}_{\mathrm{f}}\right)$, dry matter of shoots $\left(\mathrm{W}_{\mathrm{pa}}\right)$, of roots $\left(\mathrm{W}_{\mathrm{r}}\right)$, leaves $\left(\mathrm{W}_{\mathrm{f}}\right)$, emergence $(\mathrm{E})$ and velocity of germination index (IVE) of crimson clover

\begin{tabular}{|c|c|c|c|c|c|}
\hline \multirow{2}{*}{ SV } & \multirow{2}{*}{ DF } & \multicolumn{4}{|c|}{ Mean Square } \\
\hline & & $\mathrm{A}_{\mathrm{f}}$ & $\mathrm{W}_{\mathrm{pa}}$ & $\mathrm{W}_{\mathrm{r}}$ & $\mathrm{W}_{\mathrm{f}}$ \\
\hline Size & 2 & $25135.52^{\text {ns }}$ & $1.9741^{*}$ & $0.0987^{*}$ & $1.8858^{*}$ \\
\hline Dates & 10 & $152532.60 *$ & $16.81 *$ & $1.0170^{*}$ & $8.1030^{*}$ \\
\hline Size $\times$ Dates & 20 & $16072.02 *$ & $0.7229 *$ & $4.1976^{*}$ & $0.6111 *$ \\
\hline Residual & 64 & 8486.79 & 0.2539 & 0.0241 & 0.1161 \\
\hline Mean & & 170.07 & 0.99 & 0.35 & 1.09 \\
\hline CV (\%) & & 54.17 & 52.51 & 44.41 & 31.29 \\
\hline \multirow{2}{*}{ SV } & \multirow{2}{*}{ DF } & \multicolumn{4}{|c|}{ Mean Square } \\
\hline & & $\mathrm{E}$ & & IVE & \\
\hline Size & 2 & $210.81^{\mathrm{ns}}$ & & $2.14^{\mathrm{ns}}$ & \\
\hline Repetition & 8 & 362.14 & & 0.76 & \\
\hline Residual & 16 & 237.48 & & 0.95 & \\
\hline Mean & & 66.59 & & 3.61 & \\
\hline CV (\%) & & 23.14 & & 27.01 & \\
\hline
\end{tabular}

Note. ${ }^{*}$ Significant at $5 \%$ probability level. ${ }^{\mathrm{ns}}$ Non-significant.

The maximum dry matter production rate $(\mathrm{Ct})$ was achieved at 112 and $140 \mathrm{DAE}$ in the plants originated from small, medium and large seeds, respectively (Figure 1b). The plants obtained thru medium size seeds presented higher $\mathrm{Ct}$ when compared to those plants obtained from small and large sized seeds. To the relative growth rate (Rw), maximum magnitude at the initial growth stage (14 DAE) were achieved to the small, medium and large sized seeds, respectively (Figure 1c), with posterior decrease until 154 DAE. As of the 84 DAE the higher Rw was verified in plants obtained from medium sized seeds.

To Aumonde et al. (2011), the Rw showed higher values at the initial phase due to the elevated photosynthetic capacity of the young leaves and its decrease as a result of the self-shadowing (Lopes et al., 1986). Perin et al. (2002), evidenced the seed size effect at the beans plants development, where there was a significant decrease in the biomass production of the stalk, root and total, in the plants originated from larger seeds, revealing them proportionally more intense, in this manner, higher amounts of reserve from seeds could result in its increment and more vigorous seedlings.

The foliar area index (L) evidenced elevated determination coefficient $\left(\mathrm{R}^{2} \geq 0.80\right)$, and until 56 DAE it had low magnitude and the highest at 112 DAE and 126 DAE to the plants obtained thru small, medium and large seeds, respectively (Figure 1d) with posterior decrease. The plants obtained from medium sized seeds presented foliar area index superior to those originated from large and small sizes. At the end of the growing cycle, there is an accentuated decrease in the index due to the foliar senescence (Aumonde et al., 2011). This index (L) is characterized by the relation between foliar area and the area where the culture is sowed, although, it can reflect in the species productivity (Favarin et al., 2002), it is also responsible for the interception of solar energy (C. P. Peixoto \& M. F. S. P. Peixoto, 2009), and being dependent of the plant foliar area (Melges, Lopes, \& Oliva, 1989).

The maximum values of the net assimilated rate $\left(E_{a}\right)$ were observed in the plants obtained from small and medium seeds at the 14 DAE, while the plants obtained from large seeds showed lower $\mathrm{E}_{\mathrm{a}}$ at 14 DAE and among the whole crimson clover cycle (Figure 1e). After the 14 DAE there was a decrease for both treatments, with abrupt increases at 112, 126 and 98 DAE, to plants acquired from small, medium and large seeds, respectively. According to Godim et al. (2008), the $\mathrm{E}_{\mathrm{a}}$ tends to be higher at the beginning of the cycle when self-shadowing is lower.

The net assimilated rate $\left(\mathrm{E}_{\mathrm{a}}\right)$ express the velocity of biomass accumulation by unit of foliar area and estimates the net photosynthesis of the canopy, what can occur in leguminous in response to the stimulus of the photosynthetic activity occasioned by the higher demand for assimilates during the grains filling (Sivakumar \& 
Shaw, 1978). Besides the difficulties involved in the comparison of the $E_{a}$ estimates (Hunt, 1982), can be inferred when the rate was affected by the seed size. In this manner, the seeds with higher amounts of reserve favored the vegetal growth, mostly due to the increase of foliar area and photosynthetic activity. Sexton et al. (1997), observed that the lowest growth rate of beans with large seeds was associated to its low activity photosynthetic.

The highest magnitudes of the foliar area ratio $\left(\mathrm{F}_{\mathrm{a}}\right)$ were obtained at 14 DAE to the plants originated from small seeds and at $28 \mathrm{DAE}$ to the medium and large sized seeds (Figure 1f). Being that, the plants obtained from small seeds presented the highest $F_{a}$ values, followed by the medium and large. As stated by Peixoto and Peixoto (2009) the $\mathrm{F}_{\mathrm{a}}$ reduction occurs because of the self-shadowing occasioned by the superior leaves on the inferiors because of the maximum leaves expansion (Barreiro et al., 2006).

The maximum value of specific foliar area $(\mathrm{Sa})$ occurred at the $14 \mathrm{DAE}$ to the plants obtained from medium an large sized seeds, and at $28 \mathrm{DAE}$ to the small seeds (Figure 1g). The plants originated from medium sized seeds presented superior Sa when compared to the other sizes. According to Aumonde et al. (2011), the Sa value decrease were the result from de increment of dry matter and stagnation of the foliar area expansion.

The differences between the dry matter partitions among the plants structure from crimson clover, besides the seeds size, were altered along the plant development (Figure 2). The plants obtained from small seeds presented the organic carbon partition similar to the other seed sizes, among the plant development (Figure 2a). Although, the inflorescence dry matter partition were lower with the medium and large seed sizes. It was verified the similarity in the dry matter partition between the different organs from crimson clover plants originated from medium and large seeds (Figures $2 \mathrm{~b}$ and $2 \mathrm{c}$ ). Even though, plants obtained from medium sized seeds presented higher partition, when compared to those from the large sized seeds treatment. 

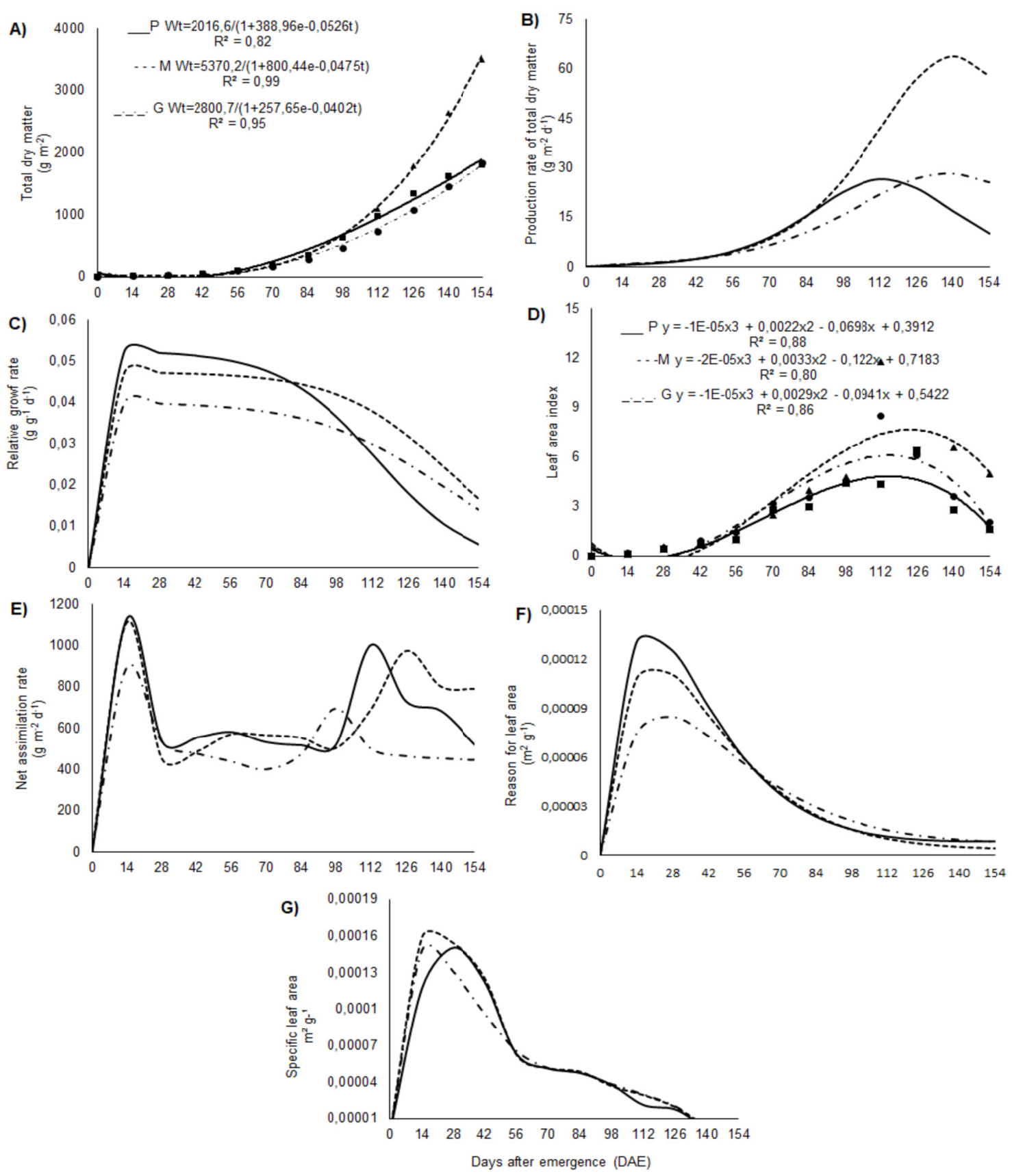

Figure 2. Total dry matter (A), dry matter production rate (B), relative growth rate (C), foliar area index (D), net assimilation rate $(\mathrm{E})$, leaf área ratio $(\mathrm{F})$ and specific foliar area $(\mathrm{G})$ of crimson clover plants among the ontogeny of plants. Being: small (-), medium (- - -) and large (----) 

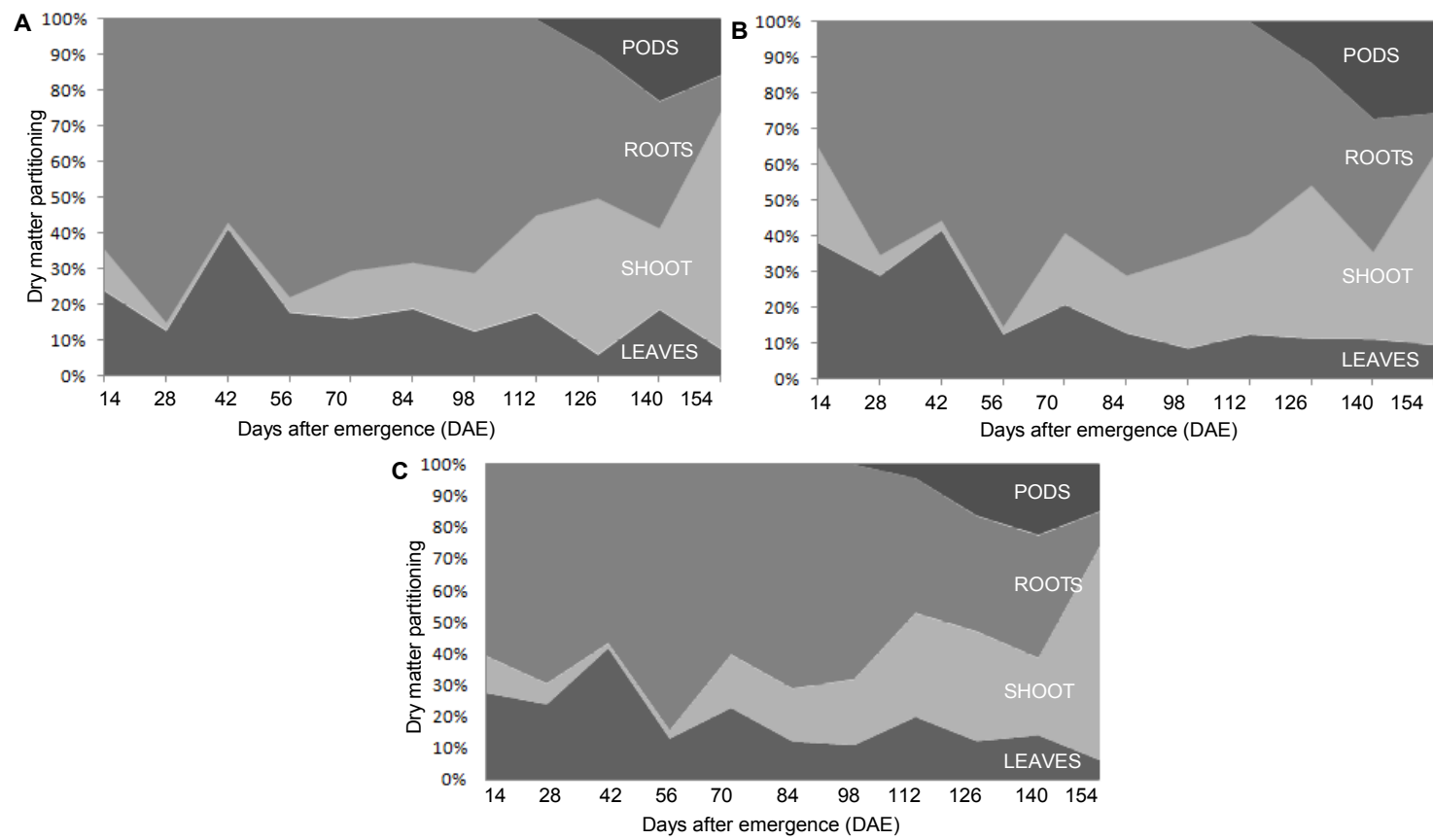

Figure 3. Dry matter partition between structures, inflorescence, foliar limbo, shoot and root, respectively, for the different crimson clover seed size. Being: (A) small seeds, (B) medium seed sand (C) large seeds

\section{Conclusion}

The seeds size effect affected the growth and the partition of the assimilated in the crimson clover plants, where medium size seeds raise the biomass accumulation in the different plants structures. Seeds of crimson clover produced from plants originated from different seed sizes did not presented difference in relation to the physiologic quality, seedling emergence and speed of emergence index.

\section{Acknowledgements}

To Coordenação de Aperfeiçoamento de Pessoal de Nível Superior (CAPES) andthe Conselho Nacional de Desenvolvimento Científico e Tecnológico (CNPq) for thescholarshipgranted.

\section{References}

Abud, H. F., Reis, R. G. E., Inneco, R., \& Bezerra, A. M. E. (2010). Emergence and development of seedlings of safflower depending on seed size. Revista Ciência Agronômica, 41(1), 95-99. https://doi.org/10.5935/ 1806-6690.20100013

Ahirwar, J. R. (2012). Effect of seed size and weight on seed germination of Alangiumlamarckii, Akola, India. Research Journal of Recent Sciences, 1, 320-322.

Aumonde, T. Z, Pedó, T., Martinazzo, E. G, Moraes, D. M., Villela, F. A., \& Lopes, N. F. (2013). Growth analysis and partitioning of assimilates in mary-nightshade plants submitted toshading levels. Planta Daninha, 31(1), 99-108. https://doi.org/10.1590/S0100-83582013000100011

Aumonde, T. Z., Lopes, N. F., Moraes, D. M., Peil, R. M. N., \& Pedó, T. (2011). Growth of Smile® hybrid mini watermelon grafted and ungrafted. Interciencia, 36(9), 677-681.

Ball, D. M., Lacefield, G. D., \& Crimson, C. (2000). Circular 00-1. Oregon Clover Commission, Salem, Oregon. Retrieved from http://www.oregonclover.org/downloads/files/crimsonclover.pdf

Barreiro, A. P., Zucareli, A., Ono, E. O., \& Rodrigues, J. D. (2006). Growth analysis of basil plants submitted to plant growth regulators. Bragantia, 65(4), 563-567. https://doi.org/10.1590/S0006-87052006000400005

Brant, V., Neckář K., Pivec, J., Duchoslav, M., Holec, J., Fuksa, P., \& Venclová, V. (2009). Competition of some summer catch crops and volunteer cereals in the areas with limited precipitation. Plant, Soil and Environment, 55(1), 17-24. https://doi.org/10.17221/378-PSE 
Bredemeier, C., Mundstock, C. M., \& Büttenbender, D. (2001). Efeito do tamanho das sementes de trigo no desenvolvimento inicial das plantas e no rendimento de grãos. Pesquisa Agropecuária Brasileira, 36(8), 1061-1068. https://doi.org/10.1590/S0100-204X2001000800008

Cazetta, J. O., Sader, R., \& Ikeda, M. (1995). Effect of size on germination performance of common bean (Phaseolus vulgaris L.) seeds. Revista Cientifica, 23(1), 65-71.

CQFS (Comissão de Química e Fertilidade do Solo). (2004). Manual de adubação e calagem para os Estados do Rio Grande do Sul e Santa Catarina. Sociedade Brasileira de Ciência do Solo (10th ed., p. 400). Porto Alegre: Editora Evangraf LTDA.

Dias, L. A. S., \& Barros, W. S. (2009). Biometria experimental (p. 408). Viçosa: Suprema Gráfica e Editora Ltda, 2009.

Favarin, J. L., Dourado-Neto, D., García, A. G., Villa Nova, N. A., \& Favarin, M. G. G. V. (2002). Equations for estimating the coffee leaf area index. Pesquisa Agropecuária Brasileira, 37(6), 769-773. https://doi.org/ 10.1590/S0100-204X2002000600005

Gondim, A. R. O., Puiatti, M., Ventrella, M. C., \& Cecon, P. R. (2008). Leaf plasticity in taro plants under different shade conditions. Bragantia, 67(4), 1037-1045. https://doi.org/10.1590/S0006-8705200800040 0028

Hackney, B., Crocker, G., Dear, B. \& Crimson, C. (2007). Primefacts-NSW Departament of Primary Industries (p. 4). Retrieved from http://www.dpi.nsw.gov.au/__data/assets/pdf_file/0009/155466/crimson-clover.pdf

Hart, A. L. (1987). Physiology. In M. J. Baker, \& W. M. Williams (Eds.), White clover (pp. 125-152). Wallinggford, UK: CAB International.

Hunt, R. (1982). Plant growth curves: The functional approach to plant growth analysis (p. 248). London: E. Arnold.

ISTA (International Seed Testing Association). (2006). International rules for seed testing (p. 303). Zurich: ISTA.

Kramberger, B., Gselman, A., Podvršnik, M., Kristl, J., \& Lešnik. M. (2013). Environmental advantages of binary mixtures of Trifolium incarnatum and Lolium multiflorum over individual pure stands. Plant, Soil and Environment, 59(1), 22-28. https://doi.org/10.17221/223/2012-PSE

Lima, A. M. M. P., \& Carmona, R. (1999). Influence of seed size on physiological seed qualityand soybean yield. Revista Brasileira de Sementes, 21(1), 157-163. https://doi.org/10.17801/0101-3122/rbs.v21n1p157-163

Lopes, N. F., Oliva, M. A., Cardoso, M. J., Gomes, M. M. S., \& Souza, V. F. (1986). Growth and emission of solar energy in Phaseolus vulgares L. submitted to three radiant flux densities and two water regimes. Revista Ceres, 33(1), 142-164.

Maluf, J. R. T. (2000). Nova classificação climática do Estado do Rio Grande do Sul. Revista Brasileira de Agrometeorologia, 8(1), 141-150.

Melges, E., Lopes, N. F., \& Oliva, M. A. (1989). Growth and conversion of solar energy to soybean cultivated under four levels of solar radiation. Pesquisa Agropecuária Brasileira, 24(9), 1065-1072.

Miyamoto, Y. (2013). Seed, the mother of agriculture (pp. 62-63). Brasília: Anuário Abrasem.

Pádua, G. P., Zito, R. K., Arantes, N. E., \& Neto, J. B. F. (2010). Influence of seed size on physiological seed qualityand soybean yield. Revista Brasileira de Sementes, 32(3), 009-016. https://doi.org/10.1590/S010131222010000300001

Peixoto, C. P., \& Peixoto, M. F. S. P. (2009). Dinâmica do crescimento vegetal: Princípios básicos. In C. A. L. Carvalho, A. C. V. L. Dantas, F. A. C. Pereira, A. C. F. Soares, \& J. F. Melo Filho (Eds.), Tópicos em ciências agrárias (pp. 37-53). Cruz das Almas: Editora Nova Civilização.

Peixoto, C. P., \& Peixoto, M. F. S. P. (2009). Plantgrowth dynamics: Basicprinciples. In C. A. L. Carvalho, A. C. V. L. Dantas, F. A. C. Pereira, A. C. F. Soares, \& J. F. Melo Filho (Eds.), Tópicos em Ciências Agrárias. (pp. 37-53) Cruz das Almas: Editora Nova Civilização.

Perin, A., Araujo, A. P., \& Teixeira, M. G. (2014). Effect of seed size on biomass and nutrient accumulation and on grain yield of common bean. Pesquisa Agropecuária, 37(12), 1711-18. https://doi.org/10.1590/S0100-20 4X2002001200006

Radford, P. J. (1967). Growth analysis formulae: Their use and abuse. Crop Science, 7(1), 171-175. 
Richards, F. J. (1969). The quantitative analysis of growth. In F. C. Stewward (Ed.), Plant physiology (pp. 3-76). New York: Academic Press.

Silva, V. N., Cicero, S. M., Silva, V. N. (2014). Seedling imaging analyze to evaluate eggplant seed physiological potential. Horticultura Brasileira, 32(2), 145-151. https://doi.org/10.1590/S0102-05362014000200004

Sivakumar, M. V. K., \& Shaw, R. H. (1978). Methods of growth analysis in field-grown soya beans (Glycine max (L.) Merrill). Annals of Botany, 42, 213-222. https://doi.org/10.1093/oxfordjournals.aob.a085442

Spaeth, S., \& Torres, S. B. (1994). Influence of seed size of Acacia gomifera on seedling development. Agropecuária Catarinense, 7(2), 5.

Szareski, V. J., Carvalho, I. R., Demari, G. H., Souza, V. Q., Rosa, T. C., Villela, F. A., ... Aumonde, T. Z. (2018b). Multivariate index of soybean seed vigor: A new biometric approach applied to the effects of genotypes and environments. Journal of Seed Science, 40(4), 396-406. https://doi.org/10.1590/2317-1545 v40n4198333

Szareski, V. J., Carvalho, I. R., Kehl, K., Levien, A. M., Nardino, M., Dellagostin, S. M., ... Aumonde, T. Z. (2018a). Evaluation of the adaptability and stability of wheat genotypes using a phenotypic index of seed vigor. Pesquisa Agropecuária Brasileira, 53(6), 727-735. https://doi.org/10.1590/s0100-204x20180006 00009

USDA (United States Department of Agriculture). (2013). Crimson Clover. Oregon, USA.

\section{Copyrights}

Copyright for this article is retained by the author(s), with first publication rights granted to the journal.

This is an open-access article distributed under the terms and conditions of the Creative Commons Attribution license (http://creativecommons.org/licenses/by/4.0/). 